\title{
Enhancing knowledge-building through communicative language teaching
}

\section{Mildred Shingirirai Nyamayedenga}

Faculty of Social \& Gender Transformative Sciences, Women's University in Africa, Harare, Zimbabwe mildrednyamayedenga@gmail.com

https://orcid.org/0000-0003-3121-6130

\section{Lizette de Jager}

Faculty of Education, University of Pretoria, Pretoria, South Africa

lizette.dejager@up.ac.za

https://orcid.org/0000-0002-5923-1490

(Received: 30 September 2020; accepted: 12 May 2021)

\section{Abstract}

Zimbabwe's new primary school curriculum aims at enhancing knowledge-building through the use of communicative language teaching (CLT) to assist both the teachers and the learners to solve problems. In this qualitative case study, we investigated the extent of teachers' inclination to use the CLT approach. To do so, the study was guided by Socio-cultural Theory (SCT) and the Experiential Learning Theory (ELT). Five purposively selected participants in the Warren Park/Mabelreign District in Zimbabwe responded to semistructured interviews and were observed while they were teaching. The analysis revealed that although teachers understood that knowledge-building can be enhanced by CLT they are ill prepared to implement it because they lack the skills and the knowledge, and they have to cope with inadequate resources. Consequently, teachers still follow traditional pedagogic practices that do not lead to knowledge-building in learners. We recommend that a number of workshops be offered to in-service teachers and stakeholders on how to employ CLT activities that enhance knowledge-building.

Keywords: communicative language teaching, experiential learning, interactive activities, knowledge-building, socio-cultural, teachers' preparedness 


\section{Introduction}

After Zimbabwean independence in 1980, the Zimbabwean Education system underwent a number of changes, of which the Nziramasanga commission of 1999 and the new curriculum of 2017 are the most significant (Esau \& Mpofu, 2017; Zhuwau \& Shumba, 2019). The introduction of the new curriculum in 2017 was triggered by the need to improve the socioeconomic status of the country by producing learners who have a Zimbabwean identity, who are honest, and who have the practical occupational skills that will allow them, eventually, to become job creators (Ministry of Primary and Secondary Education (MoPSE), 2014; Esau \& Mpofu, 2017). MoPSE (2014, p. 22) stated that the introduction of the new curriculum is a way to "establish some strong scientific, mathematical and technological oriented learners to meet moral values, national identity, pride, civic obligations and value country heritage." Scholars like Walsh (2016) have supported curriculum change by explaining that it enables teachers and stakeholders in the educational sector to reflect on teaching and learning content and methods and keep pace with wider societal developments. While the implementation of the new curriculum was a positive move to realign the curriculum to national aspirations, curriculum change, although desirable, is always complex in its involving a series of obstacles (Bennie \& Newstead, 1999). These include a lack of clarity with respect to the essential expectations and objectives of such change, the boundaries of the content, the methods of teaching, and the assessment criteria. The new curriculum has exerted some form of pressure on schools and teachers to teach learners for the future. The new curriculum commends the use of the continuous assessment mode (MoPSE, 2014). This resulted in learners continually doing projects in their learning areas which will, at the end of the school year, form part of their final exit assessments. Project work, as an interactive activity, is used in Communicative Language Teaching (CLT) to assist learners to learn communicatively and to build knowledge while they do research. This process of research to which learners are exposed through project work will enhance knowledge-building in that learners will improve on their old knowledge and create new knowledge. For project work in CLT, learners may be asked, for example, to read true-life texts, make notes, or record information in a descriptive way (Miller \& Krajcik, 2019). Knowledge-building can be achieved only if teachers assist learners to do so through facilitation and guidance in project work (UNESCO, 2005).

Knowledge-building in the teaching of English as a second language can be achieved through the use of CLT by allowing learners to be interactive. It also gives them the opportunity to put into practice their communication skills and thus create meaningful interaction (Toro et al., 2019). The efforts to implement such new curriculum change, however, are fraught with problems and its implementers are experiencing difficulties using CLT to implement it smoothly (Ngwenya, 2020). Although MoPSE has claimed that pertinent measures were taken for the curriculum to be implemented from 17 January 2017, these claims are contradicted by the Teachers Union in Zimbabwe and by parents (Mugadzaweta, 2017; Nkala, 2017). We agree with Ahmad and Lukman (2015) who pointed out that curriculum implementation should be meticulously supervised to ensure that it stays on course, but we note that it has been two years since the new curriculum was introduced and there are still reports of problems with its implementation. We propose that in order for teachers to enhance 
knowledge-building in the new primary school English Language curriculum, they need to be prepared to use CLT effectively. We sought to explore the level of such preparedness of primary school teachers to enhance knowledge-building through the use of CLT in implementing the new English Language curriculum.

According to the new curriculum, teachers are expected to enhance knowledge-building through the use of the CLT approach to produce learners who can create knowledge that will change their behaviour and help them influence their surroundings. Learners are expected to be critical thinkers and problem solvers. According MoPSE (2014) knowledge-building is best supported through interaction that helps learners share and create knowledge to enable them to undertake tasks that include activities that resemble those found in the real world (Bereiter \& Scardamalia, 2014). The use of the CLT approach may assist learners to build knowledge that will, in turn, assist them to fit into the socio-economic environment when they leave school (MoPSE, 2014). Studies on the new curriculum have been done in South Africa and elsewhere (Mashele, 2018). Bennie and Newstead (1999) carried out a study of obstacles to implementing a new curriculum in mathematics. Some of their findings were that teachers lacked adequate knowledge and that learners did not have the pre-knowledge that could serve as a foundation for the new curriculum. A study by Mandukwini (2016) on challenges surrounding curriculum implementation in high schools in Mount Fletcher District, Eastern Cape, South Africa, found that there was a lack of resources and that teachers had heavy workloads. Although some of the challenges found in other studies may be similar to those found in Zimbabwe, in this research we address a particular issue with regard to the knowledge gap. It would seem that limited research in the Zimbabwean primary school context has investigated the teachers' preparedness to enhance knowledge-building in the new curriculum at primary school level through the CLT approach.

It is against the above background that we undertook our study. The following research question guided it.

- What is the level of preparedness of primary school teachers in Zimbabwe to enhance knowledge-building through the CLT approach in relation to the new curriculum?

\section{Communicative language teaching for knowledge-building}

According to Ma et al., (2019), knowledge-building is viewed as giving learners collective responsibility for improving ideas they care about. Scardamalia and Bereiter (2006) have described knowledge-building as an attempt to modify education in an important way so that it becomes an intelligible effort to induct students into a knowledge producing culture. We define knowledge-building in terms of learners working collaboratively to produce and improve knowledge and ideas. In language teaching, one of the best ways of enhancing knowledge-building is the CLT approach that is defined as a method of teaching using communication for learners to express their ideas, feelings, and thoughts (Toro et al., 2019). Richards (2006, p. 2) defined CLT as an approach to foreign or second language teaching that emphasizes that "the goal of language learning is communicative competence." Littlewood 
(1981, p. 1) elucidated that "one of the most characteristic features of communicative language teaching is that it pays systematic attention to functional as well as structural aspects of language, combining these into a more fully communicative view." Moss and Ross-Feldman (2003) stated that CLT is any activity given to the learners that involves using communication to speak to and listen to their peers. We conclude that CLT is an approach that uses communication for learners to develop and create knowledge and to express ideas about specific topics under discussion. Given this definition of CLT it is imperative that teachers enhance knowledge-building by using activities that are interactive. Celce-Murcia (1991) and Littlewood (1981) suggested that activities include role play, group discussions, watching videos or films, answering guided questions, debates, jigsaw activities, and question and answer sessions in teaching. These activities help learners to build knowledge through interaction with others. The CLT approach is recommended in the new Zimbabwean curriculum and resonates well with knowledge-building since it can be used by teachers to assist learners in creating new knowledge through interaction. First, the use of CLT in the new curriculum helps both teachers and learners to achieve knowledge-building through teacher-to-learner and learner-to-learner interaction (MoPSE, 2014). Second, CLT assists in knowledge-building because learners are responsible for their own learning as they produce their own knowledge and ideas, while teachers act only as facilitators. Learning English as a second language will occur as a result of learners' interaction in creative knowledge work (Ma et al., 2019). Teaching and learning methods such as doing field work, demonstrations, simulations, and role play along with engaging in group work, projects, drama, debates, and research should therefore be used for knowledge-building in English second language classes (Maarof, 2018). It will be difficult for learners not to learn if they participate in authentic knowledge creation. We, therefore, sought to explore the preparedness of primary school teachers to enhance knowledge-building through the implementation of the CLT approach in the new English Language curriculum.

\section{Conceptual framework}

Socio-cultural Theory (SCT) (Vygotsky, 1978) and Experiential Learning Theory (ELT) (Kolb, 1984) were adopted in this study because both resonate well with knowledge-building and CLT through the aspects of interaction, scaffolding, and collaborative learning in the creation of new knowledge. The core concepts of the two theories maintain that learners' critical thinking levels originate from the collaborative learning or interaction they have with their peers before they transfer to an individual's thinking level (Wertsch, 2008; Xiangui, 2005). These theories share the view that interaction is one of the key elements that help learners to construct new ideas and knowledge. This is supported by Brown and Gaskins (2014), and Luna Scott (2015) who claimed that new knowledge may be constructed when learners socialise with their peers. This implies that for teachers to help learners in knowledge-building, participatory activities, talk, and collaborative work should be used in English lessons (Cross, 2010; Vygotsky, 1978). This may be done if the teacher uses the recommended CLT activities that help learners to work together and build knowledge. 
The principles of SCT and ELT are based on learners being given challenging activities to facilitate learning. Learners should work cooperatively on given activities that expose them to new information, and that assist them to contribute to, adopt, and circulate the new knowledge to their peers (Knutson, 2003). Both SCT and the ELT activities given to learners should form part of the learners' experiences, thus building knowledge. The two theories can illuminate how the learner and the teacher build new knowledge through interaction, a tenet of CLT (Kolb, 1984; Vygotsky, 1978). The core aspects of these two theories guided us in analysing the data.

\section{Research design and methodology}

The study was qualitative in nature. Gay et al., (2011, p. 7) have stated that "qualitative research is the collection, analysis and interpretation of comprehensive narrative (i.e., nonnumerical) data to gain insights into particular phenomenon of interest." Therefore, the qualitative research we undertook sought to probe deeply into the research setting to obtain an in-depth understanding of the preparedness of the primary school teachers to implement the new curriculum using CLT in knowledge-building.

Data was collected and triangulated through non-participatory observations and semistructured interviews with teachers. We conducted the interviews and non-participant observations to obtain information about the teachers' preparedness to implement the new curriculum using the CLT approach. During observations we acted as outsiders and made sure that we did not interfere during the lessons. We brought into the classroom the observation checklist that guided us in recording information on the preparedness of teachers in knowledge-building using CLT. Non-participant observation was the main data collection instrument while we used interviews to crosscheck if teachers were adequately prepared and were implementing the new curriculum to assist learners in knowledge-building. We were concerned to collect rich data so that we could use it inductively to develop insights and generalisations from it. In this way teachers' preparedness was brought out clearly. Both data sets helped us to understand the extent of the teachers' preparedness to implement the new curriculum using the recommended CLT approach.

\section{Participants and sampling procedures}

Five participants were purposively selected. The criteria used were that they had to be holders of a Diploma in Education and had to have been teaching prior to the introduction of the new curriculum. The sample was comprised of five teachers from five primary schools in the Warren Park/Mabelreign District. Following Denzin \& Lincoln, 2005, Kaiser, 2009, and Maree, 2007, for ethical reasons related to confidentiality, we have not disclosed the names of the participants or of their schools. We obtained permission from The Ministry of Education Director, the District Officer, and the Head Teachers. 


\section{Findings}

Through the interviews held with the teachers and the observations we made, the level of the teachers' preparedness to implement CLT to build new knowledge emerged. The main findings of this study show that the teachers' preparedness to enhance knowledge-building through the implementation of CLT in the new curriculum was affected by a lack of resources and teaching materials, poor planning, overly large groups, insufficient time, and the high demands of the new curriculum. Through the observations we established how teachers' enhanced knowledge-building in learners through the use of CLT in their classrooms, while the interviews cross checked their understanding of how they should enhance knowledge given the expectations of the new curriculum.

\section{Limited resources to implement the new curriculum}

The main obstacle to enhancing knowledge through the use of CLT for knowledge-building was the shortage of textbooks and teaching aids. All the participants felt that the new curriculum was ill planned. Communicative language teaching had always been recommended but because of the lack of resources, it was never implemented.

Participant 1 said, "Our school has not bought the new curriculum textbook; we only have one copy that we share as Grade 5 teachers."

Participant 2 added, "We have started implementing the new curriculum, but we have a lot of challenges in terms of the textbooks and ICT gadgets to implement it effectively."

Participant 3 explained, "I am not given learning aids to assist learners to interact among themselves. As a result, I use the chalk board and talk to the learners."

Participant 4 said,

I do not use interactive activities anymore. I used to buy Manila to make learning aids but with the economic hardship now I cannot subsidise the school and the government. In the old curriculum we were using CLT and in this new curriculum it is still recommended. However, our government has not improved in allocating us proper resources to implement it effectively. We thought the government would be prepared in this new curriculum.

From these findings it is clear that the participants agreed that the new curriculum could have brought changes to the activities and methods used. However, teachers still do not have the resources and, as a result, it is difficult for them to teach learners using interactive activities like group work, role play, and discussions. While they agreed that communicative language teaching activities can assist learners to build and create new knowledge, they attributed the poor implementation of CLT to a lack of resources. This finding echo those of Richards and Rodgers (2014) who noted that it is difficult to build knowledge through CLT when there is a dearth of resources. Teachers indicated that it was now expensive to buy even Manila paper 
and permanent markers to make simple learning aids like work cards that could assist learners to interact effectively and build new knowledge. These finding agree with those of Esau and Mpofu (2017) who claimed that curriculum implementation could not be done successfully if adequate resources for implementation were not in place.

Participating teachers indicated that the government did not supply the textbooks required to teach the new curriculum. Furthermore, the teachers could not photocopy the textbooks for fear of copyright infringement. Given the shortage of learning materials, these findings suggest that MoPSE was ill prepared for the implementation of the new curriculum that advocated for knowledge-building through the use of CLT.

Participants applauded the inclusion of research which is presented as a CLT activity in the new curriculum. They all concurred that if learners were required to do research, they would be able to build knowledge. The new curriculum encourages the use of information communication technology (ICT) for enhancing knowledge-building (MoPSE, 2014). However, the challenge of limited resources was once again apparent. Teachers believed that using computers, which is a compulsory activity in the new curriculum, would assist in knowledge-building through research activities. Their assumption is supported by Kalaš et al., (2012) who noted that learners apply research skills as they use computers to search for information and they create knowledge while determining if the information is correct, appropriate, and valuable. They also believed that computers would make it easy for learners to easily access some information that would benefit their research projects. However, while it was compulsory to use computers, schools did not have enough of them to allow learners to do such research. The other problem that prevented the teachers from enhancing knowledgebuilding through the use of computers were regular power cuts. These also interrupted learners' use of computers and this compromised their knowledge-building endeavours. All participants agreed that the government should have taken the issue of resources into consideration prior to introducing the new curriculum.

\section{Time allocated to classes is inadequate}

During the interviews, the participants indicated that too little time was allocated to the teaching of English Language. They said that double periods were required to teach the subject meaningfully and interactively since it was impossible for learners to build new knowledge within the short periods provided for in the timetable. Participant 3 said,

When the new curriculum was introduced, it seems the Ministry did not take the consideration of time. We have other subjects like Physical Education that require pupils to change into the right attire and to move from the class to the learning areas.

These take our time.

And Participant 5 explained that

the new curriculum did not change the time allocation of subjects, but it added more content. We are still finishing school at $4 \mathrm{pm}$ yet the subjects are many. This is putting 
pressure on us. In addition, we are expected to produce written exercises as per Ministry's recommendation of two written exercises in English every day, one composition every week, and two comprehension passages per week.

The findings reveal that the time factor has affected the teacher's preparedness to enhance knowledge-building through CLT. All the participants agreed that the CLT approach worked well and assisted in knowledge-building. They highlighted that perhaps they could have been in a position to use it if only they were not required to meet the demands of the Ministry of Education (Circular No 36 of 2006) as listed above. The teachers are under pressure to cover the syllabus, but the limited time allocated for the teaching of English Language compromises the quality of education since the time for learners to build knowledge is limited. This finding is similar to Chang's (2011) who found that CLT activities are time consuming, and that it takes time for teachers to explain how to do given tasks. It would appear that the time factor has adversely affected knowledge-building through the use of CLT in curriculum implementation in Harare Metropolitan primary schools.

\section{Difficulties with implementing group work as a recommended teaching method}

The new curriculum recommends the use of the CLT approach in the teaching of English Language to enhance knowledge-building. However, the findings in this study show that teachers used mainly group work as the preferred activity because they found it easier to manage. We observed that the teachers divided the learners into large groups of eight, which did not positively impact individual performances in knowledge-building. We found that the groups were too large for communicative learning to take place. As a result, some learners did not participate but played around while one or two members in the group did the work. We also presumed that the teachers had challenges in organising and monitoring all the learners in a large group during the learning process. These findings agree with those of Burke (2011) and Chang (2011) who found that large groups were ineffective in relation to interaction since learners' chances of participation were reduced, thus stifling knowledgebuilding. Participants agreed that the interactive activities recommended in the new curriculum were not easy to use because not all learners in the large groups were able to participate. This is in line with Coskun's (2011) finding that teachers did not have the relevant skills to apply and use CLT interactive activities to enhance knowledge for large groups.

Participant 1 commented, "We only use group work when we are being assessed by the head teacher because they expect us to use interactive activities according to the new curriculum.

Participant 2 said,

I only use interactive activities when I am being visited by my administrators or the district. I prefer using the traditional methods of teaching because they are fast, and I manage to complete my day's work. Now I cannot afford using interactive activities 
because subjects like agriculture and PE are now examinable, so I am forced to teach them.

Participant 3 explained,

CLT is a good method but to be honest, as you observed me, I cannot afford to use it. Group work is easy to use but it needs time. With the new curriculum you have to race otherwise you get in trouble with the authorities. We have record books which have to be up to date and are time consuming.

Participant 4 felt that

teaching is teaching, it does not matter which method you use. All I want is for my class to . . . pass. I have been producing good results; parents and my colleagues want their children to be in my class. I use the traditional methods and when there is need to use interactive activities, I do use [them].

We observed that when the participants used group work their lessons did not end on time. For example, Participant 4's lesson took more than an hour instead of the scheduled 30 minutes. We concluded that although the use of pair and group work seemed to align the observed lessons to the demand of the use of CLT in the new curriculum, it was not used effectively. The use of group work was restricted by the participants' failure to manage it, so it became time consuming. Participants believed that it was one of the interactive activities that they could easily use, but as is clear, they did not use group work effectively. This was because the teachers themselves had limited skills in running CLT activities for group work effectively. This finding aligns with those of Chang (2011) and Rahman et al. (2018) who found that teachers had poor understanding of how to handle CLT activities. The use of group work is one of the activities required and recommended by the new curriculum because it creates natural dialogue that helps learners in knowledge-building. However, participants in this study failed to implement group work effectively.

\section{Teachers engage in teacher-centred learning}

All observed lessons indicated that learners were restricted to answering questions and receiving commands from the teacher and this does not support the principle of CLT and knowledge-building during which process learners are required to create knowledge and negotiate meaning. Learners were not given opportunities to engage in sustained interactions with the teacher and they were afforded even fewer opportunities to interact among themselves. Teachers asked simple questions which allowed learners to give factual answers. Once the teachers discovered that learners knew the answers they were satisfied and did not require any additional information from them. This kind of teaching did not enable learners to interact effectively nor to develop the desired language skills. Al-Zahrani and Al-Bargi (2017) proposed that teachers should engage their learners by asking the kinds of questions that enable them to interact and build knowledge; this was not the case in the classes we 
observed. We could see that the participants employed more traditional methods of teaching and it appeared as though they were not conversant with the CLT approach.

\section{Insistence on rote learning}

During the class observations we noticed that teachers used a lot of drilling or rote learning, but this is not recommended in the new curriculum as a way of building knowledge. Learners were asked to repeat through chorusing in order to memorise what they were being taught. Once a learner gave the correct answer, the entire class repeated it. Participants conceded to the use of repetition as a way of assisting learners to grasp what they were being taught. They believed that repetition assisted learners to commit this to memory for examination purposes. Rote learning, repetition, and memorising stands in stark contrast to knowledge-building that is based on learners constructing their own knowledge through interaction (Mertens, 2014; Thomas, 2017).

\section{Exclusion of teachers in curriculum planning}

Interviews revealed that teachers possessed important information on, and understanding of, what the new curriculum entailed. Participants indicated that the challenges in the implementation of the new curriculum resulted from teachers not being consulted at the planning stage.

Participant 2 said, "The Ministry did not consult us on the planning of the new curriculum. We would have suggested to them not to recommend CLT in the new curriculum because it never worked in the old curriculum."

Participant 3's point was that "CLT in the new curriculum needed the Ministry to sit with the teachers and speak about the resources before they implemented it."

Participant 4 explained, "The Ministry always makes the mistake of not consulting and involving teachers in curriculum planning. They forget we are on the ground and we know which approach works and which one does not work."

Participant 5 said,

The Ministry of Primary and Secondary Education should change their attitudes towards us as teachers. They are ever giving us instructions from their offices. They forget we are the classrooms practitioners who know the challenges found in the classrooms and have the answers to these challenges.

\section{Teacher incapacity in implementing CLT in the new curriculum}

The findings of this study show that teachers did not have the capacity in terms of knowledge and skills to use CLT to enhance knowledge-building and were therefore ill prepared to do 
so. Prior to the introduction of the new curriculum teachers needed to attend empowering workshops and staff development courses. These would have capacitated them with knowledge and skills in relation to using CLT in implementing the new curriculum. Quyen and Khairani (2017) were of the opinion that teacher knowledge is the biggest factor in the implementation of any new curriculum.

Participant 1lamented, "I do not know what this new curriculum requires. I am using traditional teaching methods of teaching and I am only concerned with my learners passing their exam."

Participant 2 said,

I think the Ministry should carry out intensive training on how we should handle the lessons using CLT to create new knowledge because as far as I am concerned, I am teaching the same content in English, and I do not have an idea of how I can use the computer for teaching the new curriculum.

Participant 3 explained,

I have attended cluster training before. I did not benefit anything during the workshop and to be honest I am not the only one. We were told that it was a training workshop, but we were simply updated on the number of subjects to be taken. A lot of subjects have been introduced at primary school and we have to take them.

Participant 4 added, "The syllabus requires me to use ICT tools, yet I do not have an idea on how to go about it."

A lack of adequate knowledge was evident during our observations. Participants still used teacher-centred methods, which did not result in knowledge-building in all the classes we observed. They were not trained in the use of computers for teaching their learners.

Participants were more concerned with giving learners information to prepare them for the examinations, and there was no evidence in the learners of any knowledge-building taking place nor was the creation of new knowledge by the learners evident. We determined that the participants did not use the CLT approach because of the lack of staff development. This meant, of course, that the teachers were ill prepared for the implementation of the new curriculum with its insistence on knowledge-building. Similarly, Schwartz (2006) found that curriculum planners did indeed put in place good educational plans, but these were foiled because curriculum users and teachers were not adequately prepared to implement the innovations.

\section{Discussion}

The findings from this study suggest that the teachers were ill prepared to enhance knowledge-building through the implementation of CLT in the new curriculum because of the lack of resources, poor planning, time constraints, their insistence on teacher-centred 
learning, the lack of the skills to implement group work, and generalised incapacity along with not having been consulted on the development of the new curriculum. As Alsubaie (2016) has reminded us, teachers are important to the planning of any new curriculum because of the knowledge, skills, and capabilities they have. In addition, teachers know what is needed and what works for the curriculum to be successful. In this study teachers believed that since they were the implementers of the curriculum, they could have assisted the Ministry in coming up with realistic time allocation, expectations, objectives, and suitable teaching methods to be included in the curriculum. This would have contributed to the teachers owning and working towards fulfilling the set goals of the new curriculum. The teachers did not approve of the Ministry preparing the curriculum and imposing it on them. Teachers acknowledged that they were not familiar with the procedures of the new curriculum. For example, they indicated that they were expected to use computers in teaching the curriculum and that they were not familiar with the technology. The teachers also lamented the unavailability of textbooks essential to implementing the new curriculum. They highlighted that their schools could not afford to buy the textbooks and that, in some cases, five classes shared one book. Teachers agreed that they were not well prepared to present the new curriculum. The workshops they attended in preparation to teach the new curriculum effectively were not sufficient. They felt that the workshops were simply a way of conveying the Ministry's expectations to them.

While the teachers lamented the challenges regarding the implementation of CLT in the new curriculum, they appreciated the inclusion of research as a new area of learning. They applauded the Ministry for including this component because it could help learners to build knowledge.

Despite the curriculum changes the findings corroborate those of other studies of this nature. Despite the efforts made by teachers to be involved in curriculum planning, nothing has changed, and this means that in spite of this new curriculum, teachers are still not enhancing knowledge through the use of CLT. However, what is novel in this study, is the cry for deeper engagement and involvement of teachers in curriculum planning.

\section{Conclusion and Recommendations}

In light of the findings and the discussion above, and in an attempt to address a dearth in knowledge enhancement, curriculum planners should seriously consider teacher involvement in the review of the curriculum in 2023. Reconsidering teacher involvement will contribute to teachers taking ownership of a new curriculum and working towards achieving its goals. It will also help the Ministry to achieve its goal of knowledge-building in learners, which form the basis for the change in the Zimbabwean curriculum. Furthermore, MoPSE needs to plan carefully so as to provide the necessary resources prior to implementing a new curriculum. Teachers should be trained and enabled to acquire the necessary skills for the implementation of knowledge-building in accordance with the demands of the new curriculum. 


\section{References}

Ahmadi, A. A., \& Lukman, A. A. (2015). Issues and prospects of effective implementation of New Secondary School Curriculum in Nigeria. Journal of Education and Practice, 6(34), 29-39.

Alsubaie, M. A. (2016). Curriculum development: Teacher involvement in curriculum development. Journal of Education and Practice, 7(9), 106-107.

Al-Zahrani, M. Y., \& Al-Bargi, A. (2017). The impact of teacher questioning on creating interaction in EFL: A discourse analysis. English Language Teaching, 10(6), 135150.

Bennie, K., \& Newstead, K. (1999). Obstacles to implementing a new curriculum. In Proceedings of the national subject didactics symposium (pp. 150-157). University of Stellenbosch.

Bereiter, C., \& Scardamalia, M. (2014). Knowledge building and knowledge creation: One concept, two hills to climb. In S. C. Tan, H. J. So \& J. Yeo (Eds.), Knowledge creation in education (pp. 35-52). Springer.

Brown, P., \& Gaskins, S. (2014). Language acquisition and language socialization. In N. J. Enfield, P. Kockelman \& J. Sidnell (Eds.), Cambridge handbook of linguistic anthropology (pp. 187-226). Cambridge University Press.

Burke, A. (2011). Group work: How to use groups effectively. Journal of Effective Teaching, 11(2), 87-95.

Celce-Murcia, M. (1991). Grammar pedagogy in second and foreign language teaching. TESOL Quarterly, 25(3), 459-480.

Chang, M. (2011). EFL teachers' attitudes toward communicative language teaching in Taiwanese college. Asian EFL Journal, 53(1), 17-34.

Coskun, A. (2011). Future English teachers' attitudes towards EIL pronunciation. Online Submission. Journal of English as an International Language, 6(2), 46-68.

Cross, R. (2010). Language teaching as socio-cultural activity: Rethinking language teacher practice. The Modern Language Journal, 94(3), 434-452

Denzin, N. K., \& Lincoln, Y. S. (2005). Introduction: The discipline and practice of qualitative research. In N. K. Denzin \& Y. S. Lincoln (Eds.), The Sage handbook of qualitative research (pp. 1-32). SAGE. 
Esau, H., \& Mpofu, J. (2017). The preparedness of primary schools to implement the grade 3 new curriculum in Zimbabwe: Case study of Bulawayo metropolitan primary schools. European Journal of Social Sciences Studies, 2(4), 104-116.

Gay, L. R., Mills, G. E., \& Airasian, P. W. (2011). Educational research: Competencies for analysis and applications (10th ed.). Pearson Educational International.

Kaiser, K. (2009). Protecting respondent confidentiality in qualitative research. Qualitative Health Research, 19(11), 1632-1641.

Kalaš, I., Bannayan, H. E., Conery, L., Laval, E., Laurillard, D., Lim, C. P., Musgrave, S., Semenov, A. \& Turcsányi-Szabó, M. Á. R. T. A. (2012). ICT in primary education: Analytical survey volume 1: Exploring the origins, settings and initiatives. UNESCO Institute for Information Technologies in Education.

Knutson, S. (2003). Experiential learning in second-language classrooms. Tesl Canada Journaurevue Tesl Du Canada, 20(2), 52-64.

Kolb, D. A. (1984). Experiential learning: Experience as the source of learning and development. Prentice Hall.

Littlewood, W. T. (1981). Communicative language teaching: An introduction. Cambridge University Press.

Luna Scott, C. (2015). The futures of learning 3: What kind of pedagogies for the 21st century? UNESCO education research and foresight.

Ma, L., Resendes, M., Scardamalia, M., \& Dobbie, K. (2019). The knowledge building network pilot project: An exploration of emergent designs to enhance collective teacher efficacy. In K. Lund, G. P. Niccolai, E. Lavoué, C. Hmelo-Silver, G. Gweon \& M. Baker (Eds.), A wide lens: Combining embodied, enactive, extended, and embedded learning in collaborative settings, 13th international conference on computer supported collaborative learning (CSCL) 2019, (1), 81-87. International Society of the Learning Sciences.

Maarof, N. (2018). The effect of role-play and simulation approach on enhancing ESL oral communication skills. International Journal of Research in English Education, 3(3), $63-71$.

Mandukwini, N. (2016). Challenges towards curriculum implementation in high schools in Mount Fletcher district, Eastern Cape (Unpublished doctoral dissertation). University of South Africa.

Maree, K. (2007). First steps in research. Van Schaik.

Mashele, S. F. (2018). The impact of curriculum change on the working lives of rural teachers (Unpublished doctoral dissertation). University of Pretoria. 
Mertens, D. M. (2014). Research and evaluation in education and psychology: Integrating diversity with quantitative, qualitative, and mixed methods. SAGE.

Miller, E. C., \& Krajcik, J. S. (2019). Promoting deep learning through project-based learning: A design problem. Disciplinary and Interdisciplinary Science Education Research, 1(1), 1-10.

Ministry of Primary and Secondary Education (MoPSE) (2014). Curriculum Framework for Primary and Secondary Education 2015-2022. Curriculum Development Unit.

Moss, D., \& Ross-Feldman, L. (2003) Second language acquisition in adults: From research to practice. http://. cal.org/caela/esl resources/digests/SLA.html

Mugadzaweta, J. (2017). Teachers' shortage dents curriculum implementation. The Herald, February 15. https://www.herald.co.zw/teachers-shortage-dents-curriculumimplementation/

Ngwenya, V. C. (2020). Curriculum implementation challenges encountered by primary school teachers in Bulawayo Metropolitan Province, Zimbabwe. Africa Education Review, 17(2), 158-176.

Nkala, S. (2017). Dadaya case against Dokora stalls. Newsday, January 9. https://www.newsday.co.zw/2017/02/dadaya-case-dokora-stalls/

Nziramasanga, C. T. (1999). Report of the presidential commission of inquiry into education and training. Zimbabwe Government.

Quyen, N. T. D., \& Khairani, A. Z. (2017). Reviewing the challenges of implementing formative assessment in Asia: The need for a professional development program. Journal of Social Science Studies, 4(1), 160-177.

Rahman, M. M., Pandian, A., \& Kaur, M. (2018). Factors affecting teachers' implementation of communicative language teaching curriculum in secondary schools in Bangladesh. The Qualitative Report, 23(5), 1104-1126

Richards, J. C. (2006). Communicative language teaching today. Cambridge University Press.

Richards, J. C., \& Rodgers, T. S. (2014). Approaches and methods in language teaching. Cambridge University Press.

Scardamalia, M., \& Bereiter, C. (2006). Knowledge building: Theory, pedagogy, and technology. In R. K. Sawyer (Ed.), The Cambridge handbook of the learning sciences (pp. 97-118). Cambridge University Press.

Schwartz, M. (2006). For whom do we write the curriculum? Journal of Curriculum Studies, 38(4), 449-457. https://doi.org/10.1080/00220270500296606 
Toro, V., Camacho-Minuche, G., Pinza-Tapia, E., \& Paredes, F. (2019). The use of the communicative language teaching approach to improve students' oral skills. English Language Teaching, 12(1), 110-118.

Thomas, G. (2017). How to do your research project: A guide for students. SAGE.

UNESCO. (2005). United Nations decade of education for sustainable development (20052014). UNESCO International Implementation Scheme.

Vygotsky, L. (1978). Mind in society. MIT Press.

Walsh, T. (2016). 100 years of primary curriculum development and implementation in Ireland: A tale of a swinging pendulum. Irish Educational Studies, 35(1), 1-16.

Wertsch, J. V. (2008). The narrative organization of collective memory. Ethos, 36(1), 120135.

Xiangui, Z. (2005). Learning theories and second language learning. CELEA Journal, 28(5), $120-127$.

Zhuwau, C., \& Shumba, M., (2018). Factors limiting smooth implementation of new curriculum in rural secondary schools of Zimbabwe: Case study of Nyanga north area, Zimbabwe. The International Journal of Humanities \& Social Studies, 6(11), 198207. 